22 Kim HJ, Fay MP, Feuer EJ, Midthune DN. Permutation tests for joinpoint regression with applications to cancer rates. Stat Med 2000; 19 335-51

23 Law CK, Yip PS, Chan WS, Fu KW, Wong PW, Law YW. Evaluating the effectiveness of barrier installation for preventing railway suicides in Hong Kong. J Affect Disord 2009; 114: 254-62.

24 Stack S. The effect of the media on suicide: evidence from Japan, 1955-1985. Suicide Life Threat Behav 1996; 26: 132-42.

25 Chan K, Lee D, Yip P. Media influence on suicide. Media's role is double edged. BMJ 2003; 326: 498
26 Alao AO, Soderberg M, Pohl EL, Alao AL. Cybersuicide: review of the role of the internet on suicide. Cyberpsychol Behav 2006; 9: 489-93.

27 Yip PSF, Law CK, Fu K-W, Law YW, Wong PWC, Xu Y. Restricting the means of suicide by charcoal burning. Br J Psychiatry 2010; 196: 241-2.

28 Hendin H, Vijayuakumar L, Bertolote JM, Wang H, Phillips MR, Pirkis J. Epidemiology of suicide in Asia. In Suicide and Suicide Prevention in Asia (eds H Hendin, MR Phillips, L Vijayuakumar, J Pirkis, H Wang, P Yip, et al): 7-18. World Health Organization, 2008.

\title{
reflection \\ On Individual Psychotherapy and the Science of Psychodynamics by David Malan
}

\section{Peter Fonagy}

At the time of its first publication, David Malan's book was unique in this country and probably internationally in integrating emerging social science methodology with the study of individual clinical cases, which dominated psychoanalytic thinking then - as it in part continues to do to the present day.

Malan's methodology was innovative, particularly in bringing transparency and reliability to a field which prior to his work was more or less impenetrable to those who were not socialised into it through personal therapy and years of apprenticeship known as psychoanalytic training. Those of us approaching the field from the outside suddenly found concepts of defence, transference, object relationships and, above all, interpretation palpable and unambiguous - and exciting. One came to Malan from reading Freud, Stafford-Clark, Charles Rycroft and other brilliant popularisers of psychoanalytic ideas, who succeeded in conveying the essence of psychoanalytic clinical discoveries and linking these to everyday experience but failed in satisfying those of us committed to various subspecialties of the science of mind - experimental psychology, cognitive neuroscience, human development, etc. We were open to be inspired but not willing to abandon the canons of natural science. With David Malan came a tradition of researchers who wanted to go beyond the hermeneutic truth criterion of psychoanalysis, and were willing to mix the methodology generalised from social and laboratory science with the insights that could be gained only from the deep scrutiny of subjectivity afforded by psychoanalysis.

Individual Psychotherapy was the first to bridge the divide. Malan was able to look at individual cases and bring to life concepts such as psychosexual development, aggression, Oedipal rivalry, and to do so in a systematic way, linking symptoms to the interplay of defence, anxiety and impulse (and past, present and therapeutic relationship) in a manner that was impossible not to follow. Yet, his approach retained the complexity of human motivation and the multilayered nature of subjective experience that all of us are aware of, but shun in our scientific pursuits because of a Wittgensteinian commitment to parsimony.

From David Malan's book followed a tradition of British psychotherapy research that in many ways leads the world because it refuses to compromise, just as he refused to. The British tradition, represented by remarkable scholars such as David Shapiro and his group in Sheffield, with a remarkable generation of students - Glenys Parry, Michael Barkham, Shirley Reynolds, Tony Roth and others speaks volumes to independence of thinking and a deeper conceptual way of systematising ideas than our North American colleagues have, in my view, ever arrived at. What made David Malan's contribution so unique was, indeed, his capacity to avoid mechanistic thought and scientism and nevertheless create a crystal-clear model that could be - as it in fact was at several points - disconfirmed.

Malan went on to pursue a new tradition of short-term psychotherapy centred on conflict and confrontation, perhaps forming a better bridge between dynamic and more active behavioural approaches. The original book was compatible with long-term therapy, although the groundwork for his brief psychotherapy model was laid by this systematisation.

David Malan was a pathfinder in bringing the words 'science' and 'psychodynamics' together in a single project. Science remains a minority pursuit among psychodynamic therapists, as most who commit themselves to this approach do so as part of a flight from statistics, neuroscience and empiricism in general. Reflecting on Malan's achievement, we cannot claim that he succeeded in converting psychoanalytic thinkers to follow his interests. He succeeded, however, in recruiting a number of us who have worked hard to try to live up to the high ambition for integration of science and meaning he set in Individual Psychotherapy. 